NBER WORKING PAPER SERIES

\title{
LABOR SUPPLY RESPONSES TO LARGE SOCIAL TRANSFERS: LONGITUDINAL EVIDENCE FROM SOUTH AFRICA
}

\author{
Cally Ardington \\ Anne Case \\ Victoria Hosegood \\ Working Paper 13442 \\ http://www.nber.org/papers/w13442 \\ NATIONAL BUREAU OF ECONOMIC RESEARCH \\ 1050 Massachusetts Avenue \\ Cambridge, MA 02138 \\ September 2007
}

Analysis is based on data collected through the Africa Centre Demographic Information System. We have benefited from the ACDIS field and data centre staff under the leadership of the principal investigator, Dr. Kobus Herbst, and Wellcome Trust Grants 065377 and 067181 . Ardington acknowledges funding from the National Institute of Child Health and Development and the National Institute of Aging R01 HD045581-01. Case acknowledges funding from the National Institute of Aging R01 AG20275-01 and P01 AG05842-14. Hosegood acknowledges funding from the Africa Centre for Health and Population Studies, The Wellcome Trust and the London School of Hygiene and Tropical Medicine. We thank Angus Deaton, Murray Leibbrandt and seminar participants for helpful comments. The views expressed herein are those of the author(s) and do not necessarily reflect the views of the National Bureau of Economic Research.

(C) 2007 by Cally Ardington, Anne Case, and Victoria Hosegood. All rights reserved. Short sections of text, not to exceed two paragraphs, may be quoted without explicit permission provided that full credit, including $\odot$ notice, is given to the source. 
Labor Supply Responses to Large Social Transfers: Longitudinal Evidence from South Africa

Cally Ardington, Anne Case, and Victoria Hosegood

NBER Working Paper No. 13442

September 2007

JEL No. H31,J20,O12

\begin{abstract}
$\underline{\text { ABSTRACT }}$
The South African old-age social pension has been much studied by both researchers and policy makers, in part for the larger lessons that might be learned about behavioral responses to cash transfers in developing countries. In this paper, we quantify the labor supply responses of prime-aged individuals to changes in the presence of old-age pensioners in their households, using longitudinal data recently collected in northern KwaZulu-Natal. Our ability to compare households and individuals before and after pension receipt, and pension loss, allows us to control for a host of unobservable household and individual characteristics that may determine labor market behavior. We find that large cash transfers to elderly South Africans lead to increased employment among prime-aged members of their households. Perhaps more importantly, pension receipt influences where this employment takes place. We find large, significant effects on labor migration among prime-aged members upon pension arrival. The pension's impact is attributable both to the increase in household resources it represents, which can be used to stake migrants until they become self-sufficient, and to the presence of pensioners who can care for small children, which allows prime-aged adults to look for work elsewhere.
\end{abstract}

Cally Ardington

University of Cape Town

South African Labour

and Development Research Unit

Rondebosch 7701

South Africa

cally.ardington@uct.ac.za

Anne Case

367 Wallace Hall

Princeton University

Princeton, N.J. 08544

and NBER

accase@ princeton.edu
Victoria Hosegood

London School of Hygiene

and Tropical Medicine

Keppel Street, London WC1E7HT

United Kingdom

and Africa Centre for Health and Population Studies

vicky.hosegood@1shtm.ac.uk 


\section{Introduction}

The South African old-age social pension has been much studied by both researchers and policy makers, in part for the larger lessons that might be learned about behavioral responses to cash transfers in developing countries. A non-contributory pension, the social pension pays more than twice median per capita African (Black) income and represents an important source of income for a third of all African households in the country. For the vast majority of South African women aged 60 and above, and men aged 65 and above, the social pension provides a generous means of support in old age. In principle the social pension is means tested, and the amount received should depend on the recipient's other income, but in practice it pays the maximum each month (currently 820 Rands) to women and men who reach pension age without access to private pensions. (See Case and Deaton 1998 for details.) Africans often live in three or four generation households, so that the social pension (which we will refer to as 'the pension') has the potential of reaching many poor children and prime aged adults.

Because the pension relies on age-eligibility, researchers can largely eliminate changes in personal behavior, undertaken to create eligibility, from the list of potential behavioral responses, when evaluating its impact. Relatedly, because pension eligibility for the African community is very well predicted by age-eligibility, we can use ageeligibility to define treatment status, allowing us to sidestep issues of selection into treatment. The pension is also generous enough to have the potential of changing behaviors in important ways.

In this paper, we will focus on whether and to what extent this large, stable source of income leads to change in the labor force attachment of the prime-aged adults in 
households containing pensioners. If households pool income, we might expect prime aged adults who share resources with pensioners to reduce their work hours, or choose not to participate in the labor market, when pension receipt begins. Alternatively, if social transfers allow households to overcome credit constraints, enabling households to bankroll potential migrants or potential work seekers who need financial support to look for jobs, then social transfers like the pension may promote employment and help households to break out of poverty traps. It is an empirical question whether, and to what extent, resources channeled into households, in the form of the pension, change the labor market behavior of household members.

To date, evidence on labor supply responses to pension receipt in South Africa has largely relied on careful analysis of cross sectional data. Bertrand, Mullainathan and Miller (2003), using nationally representative cross-sectional data, find that prime-aged adults living in three generation households with pensioners have significantly lower rates of labor force participation than do those in three generation households without a pensioner. They conclude that "the pension dramatically reduces the labor supply of the prime-age members of the household." Using the same data, Posel, Fairburn and Lund (2006) argue that the labor supply effects are more nuanced: households with pensioners may be observed with lower labor force participation among resident prime-aged members, but these households are significantly more likely to have members who have migrated either to work or to look for work. These authors argue that this effect may be due to credit constraints, or to the need potential migrants have for an adult to be at home to care for children left behind - a role that could be played by pensioners. 
In this paper, we identify individual labor supply responses to the Social Pension using longitudinal data recently collected in northern KwaZulu-Natal (KZN). Beginning in January 2000, the Africa Centre for Health and Population Studies has followed members of approximately 11,000 households in the Umkhanyakude District of KZN. Because the survey has been carried out in multiple waves, we can examine changes in employment and migrant status between waves, given changes in household pension status. We examine the effect of household pension receipt, and pension loss, on labor force participation for all prime-aged adult members of households in the Demographic Surveillance Area (DSA). The longitudinal nature of these data allows us to use the timing of events - pension receipt, migration, labor force participation - to estimate causal pathways. Our ability to compare households and individuals before and after pension receipt, and pension loss, allows us to control for a host of unobservable household and individual characteristics that may determine labor market behavior.

When we estimate labor supply effects using only cross-sectional data from the household socioeconomic survey, we replicate many of the findings from the earlier cross-sectional analyses. Similar to Bertrand et al, we find a negative and significant relationship between the presence of a pensioner in the household and employment among prime-aged adults who are co-resident with the pensioner. As did these earlier authors, we find this result is driven by prime-aged men living with pensioners being less likely to be employed. Similar to Posel et al, we find prime-aged adults are significantly more likely to be labor migrants (that is, residing outside the DSA and reported to be working) when their households in DSA include a resident adult age-eligible for the 
pension. Like these authors, we find this effect is larger for women than for men, although in our data the associations are positive and significant for both.

When we turn to longitudinal analysis, we find a small positive increase in the employment of prime-aged adults once pension receipt begins in their households. The larger effects, however, regard where that employment takes place. Prime-aged adults are significantly more likely to be labor migrants after pension receipt begins in the household. On the flip side, we find individuals in households that lose pension eligibility between rounds of the survey are significantly less likely to be labor migrants once the pension is lost.

The paper proceeds as follows. Section 2 presents details on the Africa Centre Demographic Information System (ACDIS), with which we will evaluate the behavioral response to the pension. Section 3 demonstrates that our results match those found in earlier cross-sectional analysis. Section 4 presents descriptive results in which we map the changes in employment and labor migration that we observe in households before and after pension receipt, and before and after the withdrawal of the pension. Section 5 presents a model of migration decision-making that can explain our descriptive findings, and evidence that our results are due both to resource constraints, and to the needs of households that must care for young children. Section 6 tests extensions and alternative explanations for our findings, and Section 7 concludes.

\section{The Africa Centre Demographic Information System (ACDIS)}

We evaluate individual and household behavioral responses to the pension using data collected on approximately 100,000 people being followed by ACDIS. The surveillance 
site, part of one of the poorest districts in KwaZulu-Natal, lies approximately 2.5 hours north of Durban. The field site contains both a well-established township and a rural area administered by a tribal authority.

Demographic data on individuals and households in the surveillance area are collected twice annually, and information on births, deaths, changes in marital status, and migration is updated at each round. To reflect the complexity of living arrangements in South Africa, data collection here allows individuals to be members of multiple households - a man may have multiple wives, each in a separate household, for example, or a woman may be recognized as a member of both her mother's and her sister's households (see Hosegood and Timæus 2005; Hosegood, Benzler and Solarsh 2005). As noted by Posel et al, in a country in which migrant work is a dominant feature of the labor market, it is essential to understand the behavior of both resident and non-resident household members. The ACDIS data allow us to do so.

During the first five years of demographic surveillance, two rounds of socioeconomic data were collected, first in 2001 and then in 2003/04. We refer to the first

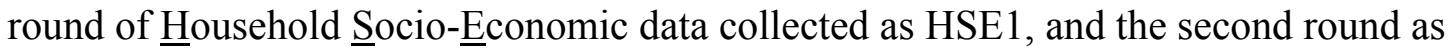
HSE2. We will use these data to measure changes in labor force participation upon pension receipt. In all that follows, we will refer to households as "receiving a pension" if they report having a member, resident in the household, who is age-eligible for the pension. This allows us to sidestep issues of selection associated with a handful of elderly persons who worked for firms that maintain a private pension for them. 
Table 1 presents relevant characteristics of individuals and households in the Demographic Surveillance Area (DSA) at the time of the second socioeconomic survey, for households that existed in both periods.

As is true for South Africa as a whole, one-third of households in the DSA report a person of pension age at HSE2. Twenty-nine percent reported receiving a pension at both HSE1 and HSE2, 5 percent became pension households between rounds of the socioeconomic survey, and 4 percent lost pension status. (As a shorthand, we will refer to individuals who are members of households that became pensioner households between HSE1 and HSE2 as having "gained pension status" between waves of the survey, and those who had housed pensioners at HSE1 but not at HSE2 as having "lost pension status.")

Households can gain a pension because someone of pension age joins the household as a resident member, or because someone already resident becomes ageeligible between waves of the survey. The latter represents the great majority ( 80 percent) of cases in which households in the DSA gained a pension between HSE1 and HSE2. Households can lose pension status either because a pensioner leaves the household or dies. In 77 percent of cases in which prime-aged adults' households lost pension status, this occurred because a pensioner died; in 11 percent of the cases, it occurred because the pensioner left the demographic surveillance area (coded as "external individual outmigration"); and in 9 percent of cases it occurred because the pensioner left the household, but not the surveillance area ("internal individual migration").

Households with pensioners at HSE2 (columns 2 and 4) are significantly larger than those that never had a pensioner and, on average, they report a significantly greater 
number of resident members. This by itself is not remarkable: in order to have a pension, the household must have at least one resident member of pension age. What is more noteworthy is that pension households contain a significantly greater number of young children (ages 0 to 5) and older children (ages 6 to 17) than do households that never had a pension. Pensioner households at HSE2 also report a greater number of prime-aged members who are working migrants. Households that were never observed with a pension are wealthier, measured by the number of assets owned by the household. These results - on relative household size, living arrangements of children, and lower socioeconomic status among pension households - are consistent with data for the country as a whole (see Case and Deaton 1998, and Edmonds et al. 2005).

Our focus will be on the behavior of prime-aged adults, which we define as men and women greater than age 17 at HSE1 and less than age 51 at HSE2. Characteristics for these individuals are presented in the bottom panel of Table 1. There is little difference between individuals who are members of households that do not have a resident member age-eligible for a pension in either period (column 1) and other prime-aged adults in terms of their ages and levels of education. However, prime-aged adults who live in households that had pensions in both periods are significantly less likely to be female (51 versus 55 percent). Both waves of the HSE asked whether every adult in the household did "anything to earn money." The household respondent is prompted to remember both formal and informal employment. There is a significantly greater employment reported for individuals living in households that never had a pension (48 percent versus 45 percent for those in households that always had a pension). In contrast, we find prime aged members of pension households to be significantly and substantially more likely to 
be working migrants (31 percent of prime-aged adults in households that always had a resident pensioner, compared with 23 percent in households that never did). Adults in households that gained a pension between the rounds of the survey are the most likely to report being labor migrants (33 percent).

In summary, households with pensioners tend to be larger and poorer on average than those that do not contain pensioners. They contain a significantly greater number of resident minors and a significantly larger numbers of non-resident working members.

\section{Cross-sectional patterns of employment and migration}

Age patterns of employment and migration can be seen in Figure 1, which presents results separately for men and women, resident and non-resident, who were ages 18 to 50 at HSE2. The probability of being employed increases from something close to zero for men and women at age 18 to approximately 65 percent for men, and 55 percent for women, in their mid-thirties. Labor migration, again defined as working and being nonresident in the DSA, also increases with age: by their late twenties, approximately 40 percent of men are reported to be labor migrants, and approximately 20 percent of women. After age 30, labor migration rates for women begin to decline, so that by their late forties only 10 percent of women are reported to be labor migrants. In what follows, we include polynomials in age when estimating employment and migration regressions that do not include individual fixed effects. These age variables adequately capture the patterns observed in Figure 1.

We examine the education pattern in employment and migration in Figure 2, where we plot, for each level of completed education, the fraction of men and women 
who are reported to be working or working migrants. Of special interest here is the role high school graduation (matric) plays in employment. (This is marked in Figure 2 using a vertical line at grade 12.) Adults who have more than a high school degree are the most likely to be employed. Those who have fallen just short of a high school degree are the least likely to be employed. Because the pattern is not linear in years of completed schooling, nor adequately captured by an indicator of having completed a certain grade, we include a complete set of indicator variables for years of completed schooling in our cross-sectional analysis.

Our results are based on the regressions of the following form:

$$
y_{i h t}^{o}=\beta P_{h t}+\gamma X_{i h t}+\varepsilon_{i h t}^{o} . \quad o=e, m
$$

For individual $i$ in household $h$ observed in survey wave $t$, our focus is on two labor market outcomes: employment ( $y^{e}=1$ if working, and $=0$ otherwise), and labor migrant status ( $y^{m}=1$ if non-resident in the DSA and reported working, $=0$ otherwise). These are modeled as a function of the presence of a resident household member age-eligible for the pension ( $P_{h t}=1$ if a pensioner is resident, $=0$ otherwise $)$. We also include in equation (1) a set of household and individual level controls $X$ that we believe independently affect employment and labor migration status. These controls will vary, depending on whether we are estimating equation (1) in the cross-section, or in the panel (where we can control for individual-level fixed effects).

Throughout our analysis, the coefficient of interest will be $\beta$. If the presence of a pensioner is associated with a lower probability of employment among prime-aged household members, for example, we would expect $\beta$ to be negative and significantly different from zero. 
We present cross-sectional regression results of the association between the presence of a pensioner and employment and migration at HSE2 in Table 2. Each coefficient presented is an estimate of $\beta$ from a different regression. Employment results are presented in the first two rows for resident members (row 1) and all members (row 2). Labor migration results are presented in the last row, where the dependent variable is equal to 1 if the individual is non-resident in the DSA and is working. The first column of the table presents results in which the effect of being a member of a pension household is estimated jointly for men and women. The second column presents results for women estimated separately, and the last column reports results for men alone. All regressions include the number of resident members in four age categories: ages 0 to 5,6 to 17,18 to 50 and above age 50. In addition, all regressions include a quartic in age, indicators for years of completed schooling, and (in column one) an indicator for sex. We allow for correlation in the unobservables of individuals who are members of the same household.

Estimates presented in row 1 are closest in spirit to those presented by Bertrand et al. Similar to their results, we find, when restricting the sample to resident members only, that the presence of a resident pensioner is associated with a three percentage point lower probability that a prime-age member is working. That this result is being driven by prime-aged resident men being less likely to be employed can be seen by comparing results in the second and third columns of Table 2 . For women, the association is very small (-0.009) and not significantly different from zero. In contrast, holding all else constant, we find that prime-aged men living in pension households are five percentage points less likely to be employed, and that this effect is significantly different from zero. 
Our specification in row 1 differs from that reported in Bertrand et al. in ways that could affect our results, but in practice do not. ${ }^{1}$ However, when we estimate equation (1), restricting our sample to three-generation households, and using the same education variable and number of resident members variables used by Bertrand et al, our results do not change in any meaningful way.

Posel et al. focus on the fact that restricting analysis to resident household members will miss an important group of working household members: labor migrants. Following Bertrand et al. (in order to make their results as comparable as possible) Posel et al. use data from the Project for Statistics on Living Standards and Development (PSLSD). The PSLSD only recorded whether there were household members who were migrants, and why they were absent (working, looking for work, etc.) but otherwise collected no information on the hours worked or earnings of the migrants. Perhaps for this reason, Posel et al. do not show how the probability of employment for all primeaged adults (resident and non-resident alike) corresponds to the presence of a pensioner in the household. We provide this information for our sample in row 2 of Table 2. Once non-resident prime-aged members are added to our analysis, we find no statistically significant association between the presence of a pensioner and the probability of employment for men and women examined separately (columns 2 and 3) or jointly (column 1). The results for men are particularly interesting: including non-resident

\footnotetext{
${ }^{1}$ Bertrand et al. control for education by including an indicator variable that an individual has completed at least grade 8. In addition, these authors control for the number of resident members, and the number of members who are ages 0 to 24, using several categories between 16 and 24. They also include 16 and 17 year olds in their analysis of employment. Bertrand et al restrict their sample to households that have at least three-generations (grandparents, parents and children), in order to reduce the heterogeneity of their sample. We prefer to include all households - primarily because the middle generation is the most likely to have migrated for work (as seen in Figure 1) and the absence of a middle-generation adult might drop the household, if we were to restrict our sample to three generations. We exclude 16 and 17 year olds, because the probability that they are employed is very close to zero.
} 
members, the coefficient on the presence of a pensioner falls from -0.05 to -0.01 , and is no longer significantly different from zero.

That the presence of a pensioner is significantly associated with labor migrant status for both men and women can be seen in row 3 of Table 2. Prime-aged women in pension households are 5 percentage points more likely to be labor migrants than are other women, holding constant age, education and household composition, and primeaged men are 3 percentage points more likely. Evidence in Table 2 is consistent with a model in which the presence of a pensioner allows prime-aged adults a greater opportunity to leave for work elsewhere.

\section{Panel estimates of the impact of pension receipt on employment and migration}

Data collected in ACDIS allow us to examine the timing of pension arrival, pension withdrawal, and changes in employment and migration. In this section, we present estimates based on longitudinal analyses of these data.

With data available from two rounds of the socioeconomic survey, we can modify equation (1) to allow for individual fixed effects. That is, the unobservable component of (1) can be written

$$
\varepsilon_{i h t}^{o}=\alpha_{i}^{o}+u_{i h t}^{o}, \quad o=e, m
$$

where $\alpha_{i}^{o}$ is an individual-specific fixed effect for labor market outcome $o$. This effect will absorb all determinants of employment $\left(\alpha_{i}^{e}\right)$ or migration $\left(\alpha_{i}^{m}\right)$ that are constant within person $i$ over time. This includes, inter alia, unobserved ability and characteristics of the household in which an individual was raised, together with his or her sex, year of birth, and (generally) years of completed schooling. A straightforward way to estimate 
the fixed effects model, given we have two observations per person, is to run changes in labor market outcomes on changes in household's pension status and changes in characteristics that may change through time:

$$
y_{i h t}^{o}-y_{i h, t-1}^{o}=\beta\left(P_{h t}-P_{h, t-1}\right)+\gamma\left(X_{i h t}-X_{i h, t-1}\right)+\left(u_{i h t}^{o}-u_{i h, t-1}^{o}\right) .
$$

Table 3 presents estimates of $\beta$ from equation (3) for employment outcomes for prime-aged members, from regressions that also control for change in the number of resident household members and the time in days between the household's survey date at HSE1 and its survey date at HSE2. The first column of Table 3 restricts the sample to prime-aged household members who were resident at both HSE1 and HSE2. With this restriction, results in column 1 can be interpreted as the first-difference analog to those presented by Bertrand et al. We find no significant association between change in household pension status and change in employment for members who were resident in both periods.

This result stands in contrast to the earlier cross-sectional results of Bertrand et al., and our results in Table 2. All of the earlier cross-sectional results may suffer from omitted variable bias: the presence of a pensioner in the household may be correlated with unobservable characteristics of the household and its members that also determine employment (Hosegood and Timæus 2005b). This explanation is consistent with additional evidence from ACDIS that pension households attract new resident members who are significantly different from new members of non-pension households. Specifically, prime-aged individuals who became resident members of pension households between the HSE survey waves were seven percentage points less likely to be employed at HSE2 than were new resident members of non-pension households. This 
difference in employment was statistically significant, with or without controls for the new members' sex, age and education. (This is a pattern documented throughout South Africa by Klasen and Woolard 2000, who find the location decisions of the unemployed are strongly influenced by the availability of economic support, often in the form of the social pension.)

It does not appear that the arrival of the pension caused these new members to stop working. Nearly 60 percent of these new unemployed members in pension households reported that they had never worked before, and almost 90 percent reported that they had not worked in the last year. Instead, it appears that pension households are significantly more likely to attract non-working resident members.

The remainder of Table 3 presents evidence of the impact of change in pension status on the employment of all members — resident and non-resident alike. Opening our analysis to all prime-aged members, we find a small, positive and significant relationship between pension receipt and employment for both men and women. A change in pension status is associated with a 3 percentage point change in employment status, on average.

With fixed effect estimation, the only individuals who contribute information for the estimate of $\beta$ are those that either gained a pension between the survey rounds, or lost a pension between the rounds. (The effects for individuals who were always living with a pensioner or who never lived with a pensioner are absorbed in those individuals' fixed effects.) Estimates in row 1 of Table 3 treat pension gain and pension loss symmetrically. That is, the employment effect of gaining the pension between rounds of the survey is assumed to be equal and opposite to that of losing the pension between rounds. We can test whether the data support this by replacing our change in pension 
status variable by two variables - one that indicates that the individual's household gained pension status, and one that indicates the household lost pension status.

Results from this estimation are presented in the lower panel of Table 3. We find, for both men and women, that the loss of a pension between rounds of the survey is associated with a lower probability of working, and the gain of a pension with a higher probability of working. Moreover, we cannot reject that these coefficients are equal and opposite in sign. The standard errors on the pension loss and gain indicator variables are quite large, however, and the estimates for pension gain are not statistically significant for men and women estimated jointly, or for women estimated alone. Overall, the results in Table 3 provide modest support for a positive impact of pension receipt on prime-aged adults' employment. They provide no evidence to support claims that the arrival of the pension has a negative causal effect on work.

Estimates of the impact of change in pension status on labor migration are provided in Table 4. Both the arrival and withdrawal of an old-age pension are significantly associated with change in migrant worker status, for both men and women. On average, individuals from households that lost pension status were 4 to 6 percentage points less likely to become or remain working migrants between HSE1 and HSE2. Individuals from households that gained pension status between HSE1 and HSE2 were 4 to 5 percentage points more likely to become or remain migrants.

A change in pension status could have different effects on current labor migrants and household members who could, potentially, become migrants. We examine whether this is the case in the last two panels of Table 4. In the third panel, we restrict our analysis to individuals who were labor migrants at the time of the first household socioeconomic 
survey (HSE1), and in the last panel, we restrict our analysis to individuals who were not labor migrants at HSE1. Dividing migrants and potential migrants highlights the fact that, on average, pension gain has a larger impact on potential migrants. Although for current migrants pension gain takes a positive coefficient — associated with maintaining migrant status - and pension loss a negative coefficient associated with losing migrant status, the estimated coefficients are not significantly different from zero. In contrast, for potential migrants, we find prime aged adults in households that lost pension status are 4 percentage points less likely to become migrants between waves, while those in households that gained pension status are 7 percentage points more likely to become migrants.

In summary, we find that prime-aged household members are significantly more likely to be employed following pension gain, and that this effect works through the increased probability that prime aged members become labor migrants upon pension receipt. We also find an asymmetry with respect to the pension's effect on labor migrants and non-migrants, with the change in pension status having a significant effect on the behavior of potential migrants, but not on those who were already working and not resident at HSE1. In the next section, we present a model of migration decision-making which we use to interpret these results.

\section{A model of migration decision-making}

The decision of whether a prime-aged man or woman will migrate for employment is likely to be determined jointly by potential migrants and members of their households who might support them, or who might rely on them for support. Migration decisions 
will depend on employment opportunities and wages inside and outside the DSA, costs associated with moving and being away, the household's need for caregivers, and household credit constraints.

We initially present a model in which women's and men's roles in the household and labor market opportunities are the same. We will return to potential differences between their circumstances once we have a model in place. Initially, we assume that households pool resources and make decisions jointly. (This will also be relaxed below.) We assume that individuals face credit constraints, and cannot borrow against future earnings. For notational purposes, we refer to the DSA as the rural sector $r$ and the destination of migrants as the urban sector $u$.

We assume that a person working in the DSA earns a wage $w_{r}$. Given the limited work opportunities available in the DSA, we assume that the wages offered there are unchanging through time, but pay well enough to meet individuals' minimum living expenses for necessities $Z_{r}$ (clothing, food and shelter)

$$
W_{r}=\bar{w}_{r}=Z_{r} .
$$

If an individual migrates to find work, he or she receives initial wage offers of $w_{u 0}$. Through the wage growth that comes with experience, or through job search once in the urban sector, wages in the urban sector rise with the time migrants spend there. The growth path of urban wages $w_{u t}$ can be characterized as

$$
w_{u t}=w_{u 0} e^{g t}+\varepsilon_{t},
$$

where $t$ is the time since arrival there, $g$ is the growth rate of wages in the sector, and $\varepsilon$ is the idiosyncratic component to wages at time $t$. 
We assume that initial urban sector wages do not cover the costs of migrating to the urban sector and expenses associated with living there, so that

$$
w_{u 0}<z_{u},
$$

where $z_{u}$ includes both living expenses and costs associated with migrating. In order to survive in the urban sector, recent migrants need to rely on financial help from members of their households in the DSA, who transfer enough resources to ensure that expenses are met. We assume that simply meeting living expenses results in an equally low-level of utility in the urban and rural sectors. With time, labor migrants' wages grow to the point that, on average, labor migrants are self-supporting. When wages exceed living expenses in the urban sector, utility is higher for labor migrants than non-migrants (whose wages are stagnant at $z_{r}$ ). At this point, labor migrants may also begin to send remittances, increasing the utility of household members in the DSA. ${ }^{2}$

For households to be able to send and support migrants for some period of time, two conditions must hold. First, total household income $Y^{H}$ must exceed that necessary to meet resident members' basic needs by more than the migrant's income shortfall. In any period $t$, in a household with $N_{t}$ resident members, household resources are sufficient to sustain a labor migrant if

$$
Y_{t}^{H}-N_{t} Z_{r}>z_{u}-w_{u t} .
$$

This is the household's financial constraint $F$.

\footnotetext{
${ }^{2}$ We do not have data on remittances, and so we do not explicitly model remittances here. However, adding remittances to the model would, in general, strengthen the household's incentives to send migrants. For the large role played by remittances in rural households in KwaZulu-Natal, see Posel 2001.
} 
Financial constraint: $\quad \begin{aligned} F & =1 \text { if } Y_{t}^{H}-N_{t} z_{r}>z_{u}-w_{u t} \\ & =0 \text { otherwise. }\end{aligned}$

Each period following migration this condition is, on average, easier to meet, given expected growth in urban sector wages.

In addition, the household must ensure that children in the DSA household are being cared for. If the household has $N_{c}$ resident children (this could be the number of children aged 0 to 5, or 0 to 7, for example) residing in the DSA household who are in need of care, the condition that must be met in order to send an adult labor migrant is

$$
\left[1-\mathrm{I}\left(R_{t}=1\right)\right] \times N_{c t}=0
$$

where $\mathrm{I}\left(R_{t}=1\right)$ is an indicator variable that takes the value of 1 if there is at least one resident adult who could care for children in the DSA in period $t$. This condition will hold either if there are no children in need of care $\left[N_{c t}=0\right]$, or if there is an adult in the DSA who could care for young children $\left[1-\mathrm{I}\left(R_{t}=1\right)=0\right]$. This is the household's childcare constraint $C$.

$$
\text { Childcare constraint: } \quad \begin{aligned}
C & =1 \text { if }\left[1-\mathrm{I}\left(R_{t}=1\right)\right] \times N_{c t}=0 \\
& =0 \text { otherwise. }
\end{aligned}
$$

The household's childcare constraint may be met, for example, if all children in need of care were able to migrate with the prime-aged adult who is considering migrating — so that $N_{c}=0$.

Equations (4) and (5) are necessary, but not sufficient, conditions for households to send a labor migrant. Equation (4) may hold, but if household members do not pool 
income, potential migrants may not be guaranteed the support they need from their households to sustain themselves in the urban sector until they find their feet. Equation (5) may hold, but if adults in the DSA household who could mind children do not agree to do so, the household's childcare needs may not be met. In what follows, these conditions help us to better understand the barriers that exist for labor migration and how those barriers change with the presence and withdrawal of pensioners.

The gain or loss of a resident pensioner in the migrant's DSA household may affect the probability that equations (4) and (5) are met and, in this way, affect the probability that a labor migrant is sent to the urban sector, stays in the sector, or returns to the DSA. Pension income generally increases $Y^{H}$, which increases the odds that the DSA household has funds to support a labor migrant until he or she becomes self-supporting. In addition, the presence of a pensioner increases the odds that there is an adult present in the DSA who could care for children.

The probability of being a labor migrant (mig) can be written

$$
\operatorname{Pr}(m i g)=\operatorname{Pr}(C=1, F=1) .
$$

We can write the joint probability as the product of the probability of meeting the childcare constraint, conditional on the probability of meeting the financial constraint multiplied by the marginal probability of meeting the financial constraint:

$$
\operatorname{Pr}(\text { mig })=\operatorname{Pr}(C=1, F=1)=\operatorname{Pr}(C=1 \mid F=1) \times \operatorname{Pr}(F=1) .
$$

We can then express the change in the probability of being a labor migrant, given change in household pension status (pen status) as 


$$
\begin{aligned}
& \operatorname{Pr}\left(\text { mig } \mid \text { pen status }_{t=2}\right)-\operatorname{Pr}\left(\text { mig } \mid \text { pen status }_{t=1}\right) \equiv \Delta \operatorname{Pr}(\text { mig }) \approx \\
& \Delta \operatorname{Pr}\left(C=1 \mid F_{t=1}=1\right) \operatorname{Pr}\left(F_{t=1}=1\right)+\Delta \operatorname{Pr}(F=1) \operatorname{Pr}\left(C_{t=1}=1 \mid F_{t=1}=1\right)
\end{aligned}
$$

The first term on the right hand side of (6) quantifies the extent to which change in pension status changes the conditional probability of meeting the childcare constraint, multiplied by the probability that the financial constraint has been met, and the second term quantifies the change in probability that the financial constraint is met, given the change in pension status, multiplied by the probability that the childcare constraint has been met. The average sizes of these two terms in (6) will vary, depending on whether individuals are labor migrants at HSE1.

\section{Labor migrants}

Labor migrants at HSE1 are meeting their financial and childcare constraints. We would not have observed them as labor migrants at HSE1 otherwise. For these individuals, then, $\operatorname{Pr}\left(F_{t=1}=1\right)=\operatorname{Pr}\left(C_{t=1}=1 \mid F_{t=1}=1\right)=1$. This simplifies the equation quantifying the change in the probability of remaining a labor migrant, for those who lost pension status between waves of the survey, to the sum of the change in the conditional probability that the childcare constraint is being met plus the change in the probability that the financial constraint is being met. For current labor migrants facing pension loss:

\footnotetext{
$\Delta \operatorname{Pr}($ mig $\mid$ pen loss $) \approx$$$
\Delta \operatorname{Pr}\left(C=1 \mid F=1 \text {, pen }_{t=1}=1, \text { pen }_{t=2}=0\right)+\Delta \operatorname{Pr}\left(F=1 \mid \text { pen }_{t=1}=1, \text { pen }_{t=2}=0\right) .
$$ 
For current labor migrants, the change in the probability of meeting the financial constraint upon pension loss may be small, if the migrant has experienced wage growth in the urban sector. In the limit, this change will be zero-once the migrant is selfsupporting. However, even self-supporting migrants may find that pension loss brings them back to the DSA, through the effect pension loss may have on the probability of meeting childcare constraints.

Labor migrants from households that gain pension status between waves of the survey should experience no change in the probability that they remain labor migrants. These migrants had already been meeting the constraints necessary for migration - that is, equations (4) and (5) already held. For these migrants, the arrival of the pension changes neither the probability that the financial constraint is met, nor the probability that the childcare constraint is met. In terms of equation (6), this implies $\Delta \operatorname{Pr}(C=1 \mid F=1)=\Delta \operatorname{Pr}(F=1)=0$. The arrival of the pension simply reinforces a migrant's ability to meet these constraints.

\section{Potential labor migrants}

In contrast, prime-aged household members who were not labor migrants at HSE1 may face binding financial constraints, or childcare constraints, or potentially both, which may be responsible for their status as potential labor migrants. In equation (6), there is a chance that one of the necessary conditions for supporting a labor migrant is not met: that is, $\operatorname{Pr}\left(F_{t=1}=1\right)$ or $\operatorname{Pr}\left(C_{t=1} \mid F=1\right)$, or both may be strictly less than 1 . This provides an additional reason why the impact of pension gain and loss on potential labor migrants may be different from that observed for current labor migrants. 
Among prime aged adults who were not labor migrants at HSE1, pension loss should reduce the probability of labor migration: subsequent to the loss of a pensioner, (4) and (5) are less likely to be met. Pension gain should increase the probability of labor migration, as (4) and (5) are more likely to hold.

\section{Predictions of the impact of pension loss and gain}

The model holds predictions for patterns we should observe in our data. For labor migrants at HSE1, the change in the probability of remaining a labor migrant for individuals from households that gained pension status between rounds of the survey should be equal to zero. Table 4 shows that this is born out in our data ( $\beta=0.021$ for this group, and is not different from zero).

For non-migrants at HSE1, changes in the probability of meeting constraints (4) and (5) are symmetric with respect to pension gain and loss. As a result we would expect the effect of gaining pension status between the rounds to be equal and opposite to the effect of losing pension status, all else held equal for this group. Table 4 suggests that this is also the case. In results for both men and women, we cannot reject at a five percent level that the effects are equal and opposite.

The model suggests additional tests of the ACDIS data. If there are no children in need of care in the DSA, then $\Delta \operatorname{Pr}(C=1 \mid F=1)=0$ and $\operatorname{Pr}\left(C_{t=1}=1\right)=1$, and the change in the probability of sending or remaining a labor migrant upon the loss of pension status simplifies, for both current and potential labor migrants, to

$$
\Delta \operatorname{Pr}(\text { mig } \mid \text { pen loss }) \approx \Delta \operatorname{Pr}\left(F=1 \mid \text { pen }_{t=1}=1 \text { pen }_{t=2}=0\right) .
$$


As discussed above, we would expect this effect to be larger for potential migrants than for current migrants, if there are fixed costs to be paid in order to migrate (which the current labor migrants have already paid), and/or if there is wage growth over time in the urban sector.

We present tests of this in Table 5, where we add an interaction term between pension loss and an indicator that the household had any resident children aged 0 to 5 at HSE1, and a similar interaction term for pension gain. The interaction terms absorb the childcare effects, while the pension loss and gain indicators standing alone absorb the financial constraint effects.

Beginning with the latter, we find, for households without young children (so that the interaction term is zero), that current labor migrants who lose pension status are not significantly more likely to lose labor migrant status between HSE1 and HSE2 than are other labor migrants. Indeed, the point-estimate on the pension loss variable is positive (0.042), but is not significantly different from zero. In contrast, potential labor migrants at HSE1 that lost pension status in households without small children are 4.2 percentage points less likely to be observed as labor migrants at HSE2 than are other potential labor migrants. This difference in the impact of pension loss between current and potential labor migrants is consistent with an asymmetry in the change in the probability that current and potential labor migrants meet their financial constraints when the pension is lost.

Among current labor migrants, we find that the presence of young children in the DSA reduces the probability that the migrant is able to maintain his or her labor migrant status upon the loss of pension status. Relative to other labor migrants, these individuals 
are 14 percentage points more likely to lose their labor migrant status upon pension loss, suggesting that the childcare constraint binds for some fraction of these labor migrants, even if the financial constraint is met. These effects are equally large for male and female labor migrants: in results estimated but not shown, the coefficient for women, estimated separately, is -0.145 , and for men is -0.122 .

Among potential labor migrants, we find that while the loss of pension status reduces the probability of being observed as a labor migrant at HSE2, the presence of small children does not interact significantly with pension loss. For these prime-aged household members, the childcare or financial constraint may already bind. To the extent that these individuals were not labor migrants because they could not meet their childcare constraint, the loss of the pension has an insignificant additional impact on the probability of meeting this constraint. The presence of the pensioner wasn't allowing the potential migrant to meet the childcare constraint, and the withdrawal of the pensioner doesn't change that.

Table 5 also supports the hypothesis that current labor migrants are insensitive to pension gain, while potential migrants are highly sensitive to the arrival of a pension. The $F$-test of the joint significance of pension gain variables for current migrants is small and insignificant $(F=0.41, p$-value $=0.66)$, while the $F$-test of pension gain variables for potential migrants is large $(F=19.51, p$-value $=0.00)$.

For potential migrants, we find significantly different effects of pension gain on labor migration for men and women. Pension arrival leads to an 11 percentage point increase in labor migration for women, which is significantly larger than the 3 percentage point increase observed for men. However, women in households with small children are 
observed with a slightly smaller ( 7 percentage point) increase, relative to other women a difference not observed for men.

The model also suggests that labor migrants should be more likely to maintain their status upon pension loss, the wealthier is their household in the DSA. Table 6 provides a test of household financial constraints by adding interaction terms to the labor migration regressions presented in Table 4 . Table 6 presents the results of regressions in which indicators that the household gained or lost a pension are interacted with markers that the household is of relatively high socioeconomic status (SES). We add these interaction terms in order to test whether households of greater means are less sensitive to the gain or loss of a pensioner, when making decisions on migration, than are other households. Greater household resources should increase the probability of meeting the financial constraint posed in equation (4).

We use, as our measure of household SES, an indicator that at least one primeaged member had a high school degree interacted with an indicator that the household owned more than 5 assets at HSE1. Using this definition, 30 percent of our prime-aged individuals are categorized as being from a high SES household. The main effect of our SES measure will be absorbed in the individuals' fixed effects. Our interest is in the interaction terms of SES and pension loss, and SES and pension gain.

For current labor migrants, we find that having come from a household of higher SES protects labor migration status upon the loss of a pension. For labor migrants at HSE1, those who came from lower SES households and lost pension status were 9 percentage points less likely to remain labor migrants than were other labor migrants. However, labor migrants from higher SES households who lost pension status face no 
greater risk of losing their labor migrant status than do any other labor migrants. The effect for migrants from high SES households that lost pension status is small $(-0.092+0.113=0.021)$, and not significantly different from zero. Consistent with the model developed above, we find no significant effects of a household gaining pension status on the probability of a labor migrant maintaining his or her migrant status.

We can also use ACDIS data to explore whether labor migrants with better jobs are significantly more likely to continue to meet their financial constraint upon pension loss. Once labor migrants are self-supporting, equation (4) becomes irrelevant for their migration decisions. For this reason, we might expect the loss of a pensioner to have a more muted effect on migration decisions for migrants with better jobs. We do not have information on how much labor migrants earn. However, we do know the migrant's occupation and education. If people in higher status occupations have higher urban wages, $w_{u t}$, then equation (4) is more likely to hold for this set of migrants. In results estimated but not shown, we interacted pension loss with being in a low-status occupation (domestic work or unskilled work), and separately interact pension loss with the migrant's own education. We find that individuals in lower-status occupations are 14 percentage points more likely to lose their labor migrant status upon the loss of a pension than are labor migrants in higher status occupations, holding constant education and household SES.

In summary, we find evidence of financial constraints and childcare constraints limiting labor migration. Both pension status - relaxing the financial constraint-and the presence of pensioners - relaxing the childcare constraint — affect the ability of households to send and maintain labor migrants. 


\section{Are All Pensioners Created Equal?}

Almost 80 percent of cases in which pension status is lost occur because a pensioner dies. An alternative explanation for the impact of pension loss on labor migration status is that the death of a pensioner induces migrants to return home.

We investigate whether death is the driving force in pension loss, by examining separately the three main reasons ways in which a pensioner leaves a household in the DSA. In $77 \%$ of cases, it is because a pensioner dies. In 11 percent of cases, it is because the pensioner has left the household and the DSA, and in 9 percent of the cases it is because the pensioner has left the household, but continues to reside in the DSA. Together these account for 97 percent of cases in which pension status was lost. Table 7 restricts attention to these three types of pension loss, and presents results on the impact of change in pension status by category on change in prime-aged adult labor migration. For both women and men, we find that pension loss through death of the pensioner, and pension loss through the pensioner leaving the surveillance site, have the same negative and significant effect on labor migration status. Both lead to a reduction in the probability of labor migration at HSE2 of 6 percentage points. In results run, but not shown, we find this to be true for current labor migrants estimated separately ( $F$-tests for these are presented in panel 2), and for potential labor migrants (panel 3).

The fact that the death of a pensioner is statistically indistinguishable from that of the out-migration of the pensioner suggest that the results we have found are not due to a death, but due instead to the absence of a pensioner and his or her pension. That said, it does not help us to distinguish between the physical presence of a pensioner and that of 
the pension. It is possible that a pensioner still in the DSA (but no longer resident in the household) could care for children and could continue to contribute to the support of labor migrants.

\section{Relatedness}

We can also examine whether the degree of relatedness between pension recipients and prime-aged household members affects prime-aged members' labor migrant status, as suggested by kin-altruism models. Bowles and Posel (2005), for example, find relatedness to be a significant predictor of migrant remittances in South Africa. Although we do not have data on remittances, and have limited information on the degree of relatedness between household members, we can identify whether pension recipients are the father or mother of prime-aged household members. Of the 1364 prime-aged members whose households gained pension status between HSE1 and HSE2, two-thirds (939) were a son or daughter of the household member who became a pensioner.

We can test whether pension gain differentially affects the children of pensioners, relative to other prime-aged adults in the household, by adding interaction terms to our labor migrant regressions. Specifically, we add interaction terms for pension loss and gain interacted with an indicator that the pensioner is the prime-aged member's parent. We find, for both men and women, that pension gain has a larger and more significant effect on the probability of potential migrants becoming labor migrants when the person newly receiving the pension is a parent. Relative to other types of members, when parents become pensioners this leads to a 7 percentage point increase in the probability of becoming a labor migrant. (Results available upon request.) 
We found no additional effects of pension loss or gain by a parent on the behavior of those adults who were labor migrants at HSE1. However, given the asymmetries between potential and current migrants discussed above, we would not expect to find effects here. Even if parents are more important than other household members in staking current migrants until these migrants become established, once the migrants are selfsupporting, the loss of a parent pensioner may have little financial effect on this group. ${ }^{3}$

\section{Male and female pensioners: who pools?}

We can also use the ACDIS data to examine whether male and female pensioners are equally likely to stake migrants. Related work has suggested that pension money in the hands of women may have a greater impact on household outcomes than pension money in the hands of men (Posel et al., Duflo 2003). Table 8 presents evidence on the difference between female and male pensioners. For both prime-aged men and women, the loss of a female pensioner has a significant negative effect on the probability of becoming a labor migrant between waves of the survey, while the loss of a male pensioner has no significant effect on either. The gain of a female pensioner between waves is associated with greater labor migration for both men and women. However, labor migration for men is also closely linked with the receipt of pension income for an older male in the household. We have tested whether the differential effect of male pensioners on the labor migrations status of potential migrants is due to the fact that, upon male pension gain, households are significantly more likely to also house a female

\footnotetext{
${ }^{3}$ It is possible that as parents and other older adults in the household become frail, labor migrants might be called back to the DSA to care for them. However, we find no evidence for this in our data. In pension households, both male and female prime-aged members were significantly more likely to be labor migrants at HSE2 the older were the pensioners in their households. (Results available upon request.)
} 
pensioner. We find no evidence for this explanation for the difference in the impact of male and female pensioners. It appears that the presence of a woman pensioner promotes labor migration for both men and women, consistent with female pensioners pooling their income with prime-aged members of both sexes, and that the presence of a male pensioner promotes labor migration, but for prime-aged men only.

\section{Conclusion}

Much of the discussion on the behavioral changes induced by government cash transfers centers on the effects such transfers may have on both the recipients of these transfers and the household members who live with them. (Excellent reviews of the literature are provided by Atkinson and Micklewright 1991, and Moffitt 1992.) Our results suggest some refocus is warranted. Large cash transfers to elderly South Africans lead to increased labor migration among prime-aged members. The pension's impact appears to work both through the effects it has on household resources and on the presence in the DSA of an adult who can care for small children.

\section{References}

Atkinson, Anthony B. and John Micklewright. 1991. "Unemployment Compensation and Labor Market Transitions: A Critical Review." Journal of Economic Literature 29(4): 1679-1727.

Bertrand, Marianne, Sendhil Mullainathan and Douglas Miller. 2003. "Public Policy and Extended Families: Evidence from Pensions in South Africa." The World Bank Economic Review 17(1): 27-50. 
Bowles, S. and D. Posel. 2005. "Genetic Relatedness Predicts South African Migrant Workers' Remittances to Their Families.” Nature 434: 380-383.

Case, Anne and Angus Deaton. 1998. "Large Cash Transfers to the Elderly in South Africa.” Economic Journal 108(450): 1330-1261.

Duflo, Esther. 2003. "Grandmothers and Granddaughters: Old-Age Pensions and Intrahousehold Allocation in South Africa." World Bank Economic Review 17(1): 1-25.

Edmonds, Eric V., Kristin Mammen and Douglas L. Miller. 2005. "Rearranging the Family? Income Support and Elderly Living Arrangements in a Low-Income Country." Journal of Human Resources 40(1): 186-207.

Hosegood, V., Benzler, J. and Solarsh, G. 2005. "Population Mobility and Household Dynamics in Rural South Africa: Implications for Demographic and Health Research." Southern African Journal of Demography 10(1\&2):43-67.

Hosegood, V. and Timæus, I. M. 2005. "Household Composition and Dynamics in KwaZulu Natal, South Africa: Mirroring Social Reality in Longitudinal Data Collection," Chapter 4 in African Households: an exploration of census data. (Ed, van der Walle, E). M.E.Sharpe Inc, New York, pp. 58-77.

Hosegood, V. and Timæus, I.M. 2005b. "The Impact of Adult Mortality on the Living Arrangements of Older People in Rural South Africa." Ageing and Society 25:431-444.

Klasen, Stephan and Ingrid Woolard. 2000. "Surviving Unemployment Without State Support: Unemployment and Household Formation in South Africa." IZA Discussion Paper No. 237.

Moffitt, Robert. 1992. "Incentive Effects of the U.S. Welfare System: A Review," Journal of Economic Literature 30(1): 1-61.

Posel, Dorrit R. 2001. "Intra-Family Transfers and Income-Pooling: A Study of Remittances in KwaZulu-Natal." The South African Journal of Economics 69(3): 501-28.

Posel, Dorrit, James A. Fairburn and Frances Lund. 2006. "Labour Migration and Households: A Reconsideration of the Effects of the Social Pension on Labour Supply in South Africa." Economic Modelling 23: 836-853. 
Figure 1. Age patterns in employment and migration
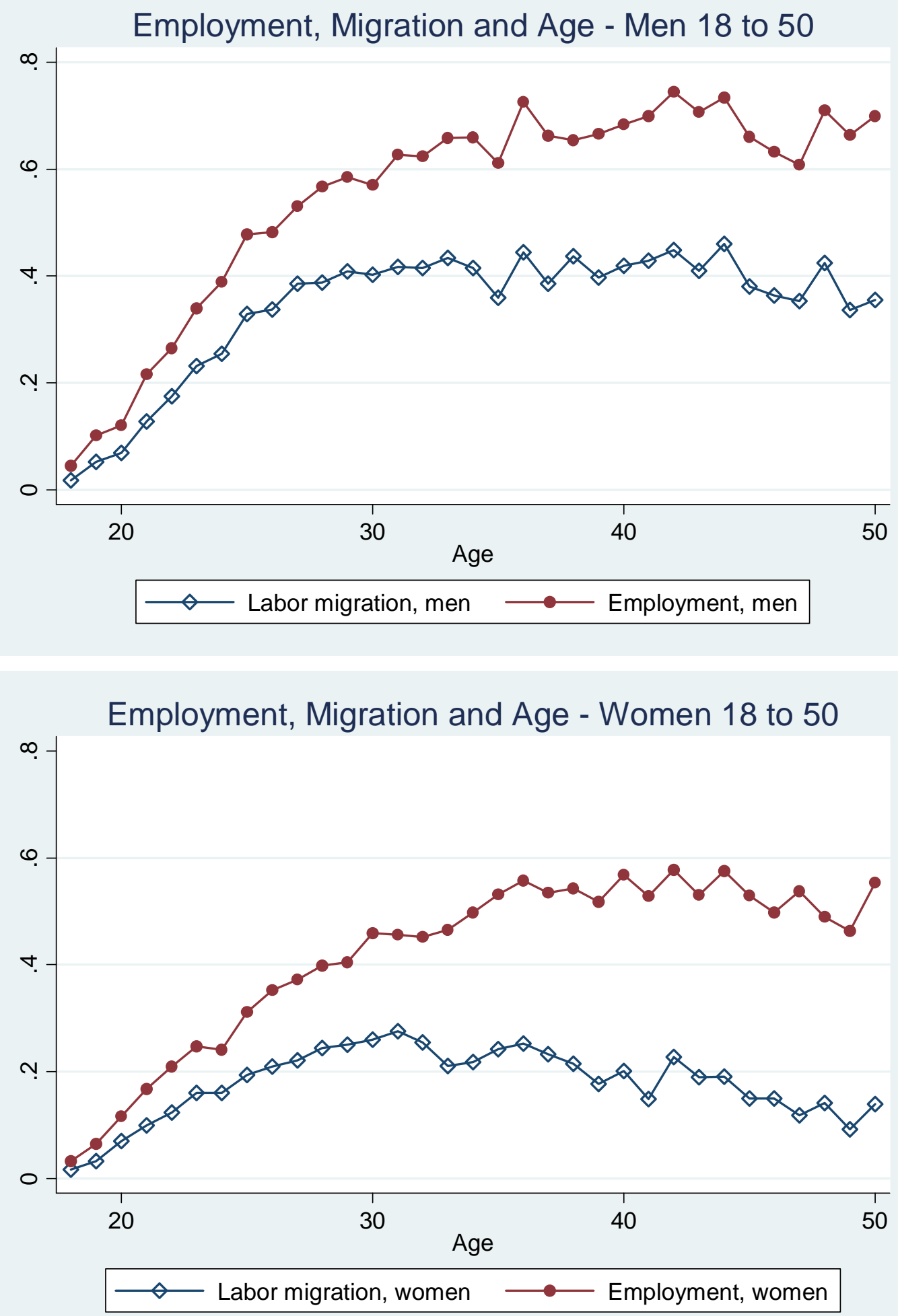
Figure 2. Education patterns in employment and migration
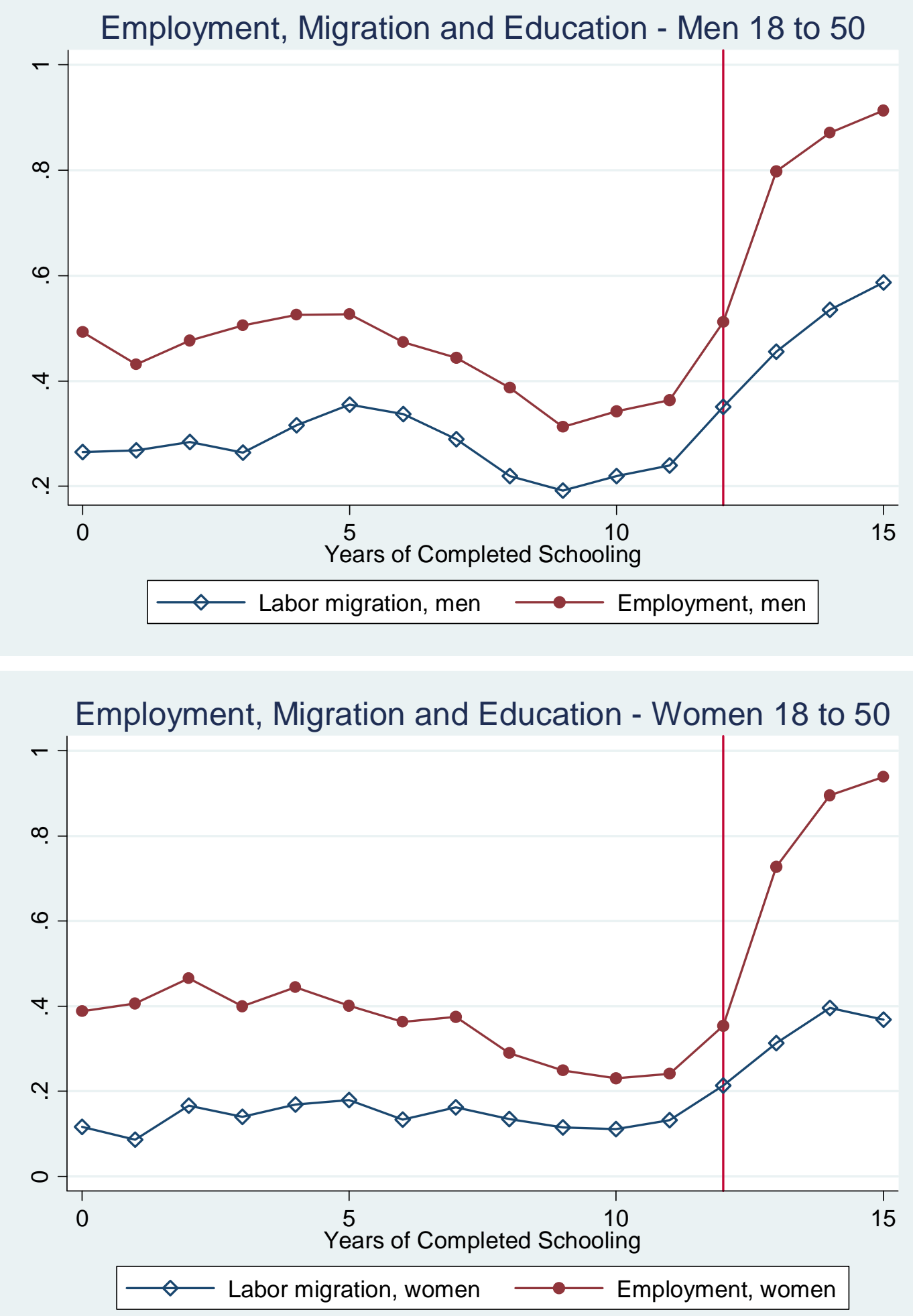
Table 1. Household and individual characteristics in the Africa Centre DSA

\begin{tabular}{lcccc}
\hline \hline & $\begin{array}{c}\text { Never had a } \\
\text { pension }\end{array}$ & $\begin{array}{c}\text { Always had a } \\
\text { pension }\end{array}$ & $\begin{array}{c}\text { Lost pension } \\
\text { status from } \\
\text { HSE1 to HSE2 }\end{array}$ & $\begin{array}{c}\text { Gained pension } \\
\text { status from } \\
\text { HSE1 to HSE2 }\end{array}$ \\
$\begin{array}{l}\text { Household } \\
\text { characteristics: }\end{array}$ & 5625 & 2661 & 342 & 465 \\
Number of households & 7.48 & $9.93^{*}$ & $8.80^{*}$ & $9.28^{*}$ \\
Number of members & 5.34 & $6.94^{*}$ & 5.57 & $6.61^{*}$ \\
Number of resident & & & & \\
members & 0.78 & $0.92^{*}$ & 0.87 & $0.98^{*}$ \\
Residents aged 0 to 5 & 2.09 & $2.44^{*}$ & 2.13 & $2.28^{*}$ \\
Residents aged 6 to 17 & 2.12 & $2.20^{*}$ & 2.27 & 2.01 \\
Residents aged 18 to 50 & 0.36 & $1.37^{*}$ & 0.30 & $1.33^{*}$ \\
Residents aged 51 + & 0.77 & $1.14^{*}$ & $0.92^{*}$ & $1.15^{*}$ \\
Number of labor migrants & 5.45 & $4.90^{*}$ & $4.80^{*}$ & $5.15^{*}$ \\
Number of assets & & & & \\
Individual \\
characteristics:
\end{tabular}

Notes. Column 1 reports means for households that did not have a resident member ageeligible for the social pension at either wave of the household socioeconomic status module (HSE1 or HSE2). Column 2 reports on households that had an age-eligible member at both waves. Column 3 reports on households that had an age-eligible member at HSE1, but not at HSE2. Column 4 reports on households that did not have an ageeligible member at HSE1 but did at HSE2. Of those households that gained a pension between the waves, 80 percent had a resident member who aged into pension age between rounds of the survey. Labor migrants are household members reported to be working and non-resident in the DSA. Asterisks $(*)$ denote that the differences between households or individuals that never had a pension and other types of households are significant at the 5 percent level. 
Table 2. Employment, migration and the presence of a pensioner at HSE2

\begin{tabular}{lccc}
\hline \hline & $\begin{array}{c}\text { Women and } \\
\text { men }\end{array}$ & Women only & Men only \\
Dependent variable: & & & \\
Employment at HSE2 & & -0.009 & -0.051 \\
Resident members only: & -0.027 & $(0.011)$ & $(0.013)$ \\
& $(0.009)$ & $\mathrm{n}=12314$ & $\mathrm{n}=8789$ \\
& $\mathrm{n}=21103$ & 0.014 & -0.012 \\
\cline { 2 - 4 } $\begin{array}{l}\text { Resident and non-resident } \\
\text { members: }\end{array}$ & 0.003 & $(0.009)$ & $(0.010)$ \\
& $\mathrm{n}=35842$ & $\mathrm{n}=19103$ & $\mathrm{n}=16739$ \\
\hline $\begin{array}{l}\text { Dependent variable: } \\
\text { Labor migrant at HSE2 }\end{array}$ & & & \\
$\begin{array}{l}\text { Resident and non-resident } \\
\text { members: }\end{array}$ & 0.045 & 0.051 & 0.034 \\
& $(0.006)$ & $(0.008)$ & $(0.009)$ \\
\hline \hline
\end{tabular}

Notes. Table 2 reports the coefficients and standard errors from OLS regressions of employment (rows 1 and 2) and labor migration(row 3) on an indicator that a household has a resident member of pension age. Also included in each regression are the number of resident members ages 0 to 5,6 to 17, 18 to 50, and aged 51 and above, a complete set of indicators for the member's years of completed schooling, and a quartic in the member's age. Unobservables are clustered at the household level. The sample is restricted to household members greater than age 17 and less than age 51 at HSE2. In row 1, it is further restricted to resident members only. 
Table 3. The effect of change in pension status on employment

\begin{tabular}{|c|c|c|c|c|}
\hline & \multirow[b]{2}{*}{$\begin{array}{l}\text { Resident } \\
\text { members } \\
\text { only }\end{array}$} & \multicolumn{3}{|c|}{$\begin{array}{c}\text { Dependent variable: } \\
\text { Change in employment status } \\
\text { HSE2 - HSE1 }\end{array}$} \\
\hline & & $\begin{array}{c}\text { All } \\
\text { members }\end{array}$ & $\begin{array}{c}\text { All } \\
\text { members } \\
\text { Women }\end{array}$ & $\begin{array}{c}\text { All } \\
\text { members } \\
\text { Men }\end{array}$ \\
\hline $\begin{array}{l}\text { Change in household pension } \\
\text { status HSE2 - HSE1 }\end{array}$ & $\begin{array}{c}0.005 \\
(0.016)\end{array}$ & $\begin{array}{c}0.033 \\
(0.011)\end{array}$ & $\begin{array}{c}0.029 \\
(0.015)\end{array}$ & $\begin{array}{c}0.036 \\
(0.016)\end{array}$ \\
\hline $\begin{array}{l}\text { Indicator: Household lost } \\
\text { pension status HSE2 - HSE1 }\end{array}$ & $\begin{array}{l}-0.011 \\
(0.024)\end{array}$ & $\begin{array}{l}-0.042 \\
(0.017)\end{array}$ & $\begin{array}{l}-0.048 \\
(0.024)\end{array}$ & $\begin{array}{l}-0.036 \\
(0.025)\end{array}$ \\
\hline $\begin{array}{l}\text { Indicator: Household gained } \\
\text { pension status HSE2 - HSE1 }\end{array}$ & $\begin{array}{l}-0.001 \\
(0.023)\end{array}$ & $\begin{array}{c}0.026 \\
(0.015)\end{array}$ & $\begin{array}{c}0.015 \\
(0.021)\end{array}$ & $\begin{array}{c}0.037 \\
(0.021)\end{array}$ \\
\hline Number of observations & 12222 & 24921 & 13183 & 11738 \\
\hline
\end{tabular}

Notes. Table 3 reports the coefficients and standard errors from OLS regressions of change in employment status (HSE2-HSE1) on change in the presence of a resident member age-eligible for the pension (HSE2-HSE1). Also included in each regression are the change in the number of resident members, and the number of days that elapsed between HSE1 and HSE2. The sample is restricted to household members greater than age 17 at HSE1 and less than age 51 at HSE2. The sample in column 1 is restricted to members who were resident at both HSE1 and HSE2. 
Table 4. The effect of change in pension status on migration for work

\begin{tabular}{lccc}
\hline \hline & \multicolumn{3}{c}{ Dependent variable: } \\
& Change in labor migrant status HSE2 - HSE1 \\
\cline { 2 - 4 } & All members & Women & Men \\
\hline Change in household pension & 0.046 & 0.056 & 0.037 \\
status HSE2 - HSE1 & $(0.009)$ & $(0.011)$ & $(0.013)$ \\
Number of observations & 24921 & 13183 & 11738 \\
\hline Indicator: Household lost & -0.049 & -0.061 & -0.038 \\
pension status HSE2 - HSE1 & $(0.013)$ & $(0.017)$ & $(0.020)$ \\
Indicator: Household gained & 0.045 & 0.053 & 0.036 \\
pension status HSE2 - HSE1 & $(0.012)$ & $(0.015)$ & $(0.018)$ \\
Number of observations & 24921 & 13183 & 11738 \\
\hline & Change in labor migrant status for those who were \\
& \multicolumn{4}{c}{ labor migrants at HSE1 } \\
Indicator: Household lost & -0.052 & -0.061 & -0.040 \\
pension status HSE2 - HSE1 & $(0.031)$ & $(0.052)$ & $(0.039)$ \\
Indicator: Household gained & 0.021 & 0.022 & 0.022 \\
pension status HSE2 - HSE1 & $(0.026)$ & $(0.044)$ & $(0.032)$ \\
Number of observations & 5283 & 2033 & 3250 \\
\hline & Change in labor migrant status for those who were \\
& \multicolumn{2}{c}{ not labor migrants at HSE1 } \\
Indicator: Household lost & -0.038 & -0.045 & -0.037 \\
pension status HSE2 - HSE1 & $(0.013)$ & $(0.016)$ & $(0.021)$ \\
Indicator: Household gained & 0.070 & 0.079 & 0.052 \\
pension status HSE2 - HSE1 & $(0.011)$ & $(0.014)$ & $(0.018)$ \\
Number of observations & 19638 & 11150 & 8488 \\
\hline \hline
\end{tabular}

Notes. Table 4 reports the coefficients and standard errors from OLS regressions of change in labor migrant status (HSE2-HSE1) on change in the presence of a resident member age-eligible for the pension (HSE2-HSE1). Also included in each regression are the change in the number of resident members, and the number of days that elapsed between HSE1 and HSE2. The sample is restricted to household members greater than age 17 at HSE1 and less than age 51 at HSE2. 
Table 5. Pension status and the impact of small children on labor migration

\begin{tabular}{|c|c|c|c|c|}
\hline & \multicolumn{4}{|c|}{$\begin{array}{c}\text { Dependent variable: change in labor migrant } \\
\text { status HSE2-HSE1 }\end{array}$} \\
\hline & \multirow{2}{*}{$\begin{array}{c}\text { Labor } \\
\text { migrants at } \\
\text { HSE1 } \\
\text { All }\end{array}$} & \multicolumn{3}{|c|}{ Not labor migrants at HSE1 } \\
\hline & & All & Women & Men \\
\hline $\begin{array}{l}\text { Household lost pension status } \\
\text { HSE2 - HSE1 }\end{array}$ & $\begin{array}{c}0.042 \\
(0.055)\end{array}$ & $\begin{array}{l}-0.042 \\
(0.022)\end{array}$ & $\begin{array}{l}-0.033 \\
(0.029)\end{array}$ & $\begin{array}{l}-0.064 \\
(0.034)\end{array}$ \\
\hline $\begin{array}{l}\text { Household lost pension status } \times \\
\text { household has children } 0 \text { to } 5\end{array}$ & $\begin{array}{l}-0.139 \\
(0.066)\end{array}$ & $\begin{array}{c}0.005 \\
(0.027)\end{array}$ & $\begin{array}{l}-0.018 \\
(0.034)\end{array}$ & $\begin{array}{c}0.042 \\
(0.042)\end{array}$ \\
\hline $\begin{array}{l}\text { Household gained pension status } \\
\text { HSE2 - HSE1 }\end{array}$ & $\begin{array}{c}0.032 \\
(0.040)\end{array}$ & $\begin{array}{c}0.077 \\
(0.019)\end{array}$ & $\begin{array}{l}0.113 \\
(0.025)\end{array}$ & $\begin{array}{c}0.030 \\
(0.029)\end{array}$ \\
\hline $\begin{array}{l}\text { Household gained pension status } \times \\
\text { household has children } 0 \text { to } 5\end{array}$ & $\begin{array}{l}-0.018 \\
(0.051)\end{array}$ & $\begin{array}{l}-0.011 \\
(0.023)\end{array}$ & $\begin{array}{l}-0.046 \\
(0.029)\end{array}$ & $\begin{array}{c}0.035 \\
(0.036)\end{array}$ \\
\hline$F$-test: Pension loss variables ( $p$-value) & $\begin{array}{c}3.65 \\
(0.026)\end{array}$ & $\begin{array}{c}4.62 \\
(0.010)\end{array}$ & $\begin{array}{c}4.38 \\
(0.013)\end{array}$ & $\begin{array}{c}2.10 \\
(0.123)\end{array}$ \\
\hline F-test: Pension gain variables ( $p$-value) & $\begin{array}{c}0.41 \\
(0.662)\end{array}$ & $\begin{array}{c}19.51 \\
(0.000)\end{array}$ & $\begin{array}{c}18.08 \\
(0.000)\end{array}$ & $\begin{array}{c}4.51 \\
(0.011)\end{array}$ \\
\hline Number of observations & 5283 & 19638 & 11150 & 8488 \\
\hline
\end{tabular}

Notes. Table 5 reports the coefficients and standard errors from OLS regressions of change in labor migrant status (HSE2-HSE1) on change in the presence of a resident member age-eligible for the pension (HSE2-HSE1). Also included in each regression are the change in the number of resident members, and the number of days that elapsed between HSE1 and HSE2. The sample is restricted to household members greater than age 17 at HSE1 and less than age 51 at HSE2. 
Table 6. Household socioeconomic status, pension status and migration

\begin{tabular}{lcc}
\hline \hline & $\begin{array}{c}\text { Labor } \\
\text { migrants at } \\
\text { HSE1 }\end{array}$ & $\begin{array}{c}\text { Not labor } \\
\text { migrants at } \\
\text { HSE1 }\end{array}$ \\
\hline Household lost pension status & -0.092 & -0.040 \\
HSE2 - HSE1 & $(0.039)$ & $(0.016)$ \\
Household lost pension status & 0.113 & 0.006 \\
HSE2 - HSE1 × high SES & $(0.064)$ & $(0.025)$ \\
Household gained pension status & -0.004 & 0.079 \\
HSE2 - HSE1 & $(0.032)$ & $(0.013)$ \\
Household gained pension status & 0.066 & -0.032 \\
HSE2 - HSE1 $\times$ high SES & $(0.052)$ & $(0.023)$ \\
F-test: joint significance of & 2.87 & 4.36 \\
Pension loss variables (p-value) & $(0.057)$ & $(0.013)$ \\
F-test: joint significance of & 1.14 & 20.38 \\
Pension gain variables $(p-v a l u e)$ & $(0.321)$ & $(0.000)$ \\
Number of observations & 5231 & 19417
\end{tabular}

Notes. Table 6 reports the coefficients and standard errors from OLS regressions of change in labor migrant status (HSE2-HSE1) on change in the presence of a resident member age-eligible for the pension (HSE2-HSE1). Also included in each regression are the change in the number of resident members, and the number of days that elapsed between HSE1 and HSE2. The sample is restricted to household members greater than age 17 at HSE1 and less than age 51 at HSE2. 
Table 7. Change in labor migration status by type of pension loss

\begin{tabular}{|c|c|c|c|}
\hline & \multicolumn{3}{|c|}{$\begin{array}{l}\text { Dependent variable: } \\
\text { Change in labor migrant status HSE2 - HSE1 }\end{array}$} \\
\hline & $\begin{array}{c}\text { All } \\
\text { members }\end{array}$ & Women & Men \\
\hline $\begin{array}{l}\text { Pension loss through death of } \\
\text { pensioner }\end{array}$ & $\begin{array}{l}-0.065 \\
(0.015)\end{array}$ & $\begin{array}{l}-0.078 \\
(.020)\end{array}$ & $\begin{array}{l}-0.053 \\
(0.023)\end{array}$ \\
\hline $\begin{array}{l}\text { Pension loss through external } \\
\text { individual out migration of pensioner }\end{array}$ & $\begin{array}{l}-0.061 \\
(0.039)\end{array}$ & $\begin{array}{l}-0.056 \\
(0.050)\end{array}$ & $\begin{array}{l}-0.065 \\
(0.060)\end{array}$ \\
\hline $\begin{array}{l}\text { Pension loss through internal } \\
\text { individual migration of pensioner }\end{array}$ & $\begin{array}{c}0.068 \\
(0.042)\end{array}$ & $\begin{array}{l}0.065 \\
(0.057)\end{array}$ & $\begin{array}{c}0.067 \\
(0.064)\end{array}$ \\
\hline Pension gain & $\begin{array}{c}0.045 \\
(0.112)\end{array}$ & $\begin{array}{c}0.053 \\
(0.015)\end{array}$ & $\begin{array}{c}0.036 \\
(0.018)\end{array}$ \\
\hline $\begin{array}{l}\text { F-test: death = external out-migration } \\
\text { (p-value) }\end{array}$ & $\begin{array}{c}0.01 \\
(.9121)\end{array}$ & $\begin{array}{c}0.17 \\
(.6845)\end{array}$ & $\begin{array}{c}0.03 \\
(.8362)\end{array}$ \\
\hline \multirow[t]{2}{*}{ Number of observations } & 24873 & 13162 & 11711 \\
\hline & \multicolumn{3}{|c|}{$\begin{array}{l}\text { Change in labor migrant status for those who } \\
\text { were labor migrants at HSE1 }\end{array}$} \\
\hline $\begin{array}{l}\text { F-test: death=external out-migration } \\
\text { (p-value) }\end{array}$ & $\begin{array}{c}0.72 \\
(.3967)\end{array}$ & $\begin{array}{c}0.09 \\
(.7622)\end{array}$ & $\begin{array}{l}2.04 \\
(.1536)\end{array}$ \\
\hline \multirow[t]{2}{*}{ Number of observations } & 5275 & 2031 & 3244 \\
\hline & \multicolumn{3}{|c|}{$\begin{array}{c}\text { Change in labor migrant status for those who } \\
\text { were not labor migrants at HSE1 }\end{array}$} \\
\hline $\begin{array}{l}\text { F-test: death=external out-migration } \\
\text { (p-value) }\end{array}$ & $\begin{array}{l}1.87 \\
(.1769)\end{array}$ & $\begin{array}{c}0.62 \\
(.4309)\end{array}$ & $\begin{array}{l}1.34 \\
(.2473)\end{array}$ \\
\hline Number of observations & 19598 & 11131 & 8467 \\
\hline
\end{tabular}

Notes. Table 7 reports the coefficients and standard errors from OLS regressions of change in labor migrant status (HSE2-HSE1) on change in the presence of a resident member age-eligible for the pension (HSE2-HSE1). Also included in each regression are the change in the number of resident members, and the number of days that elapsed between HSE1 and HSE2. The sample is restricted to household members greater than age 17 at HSE1 and less than age 51 at HSE2. 
Table 8. The impact of a gain or loss of male and female pensioners on labor migration

\begin{tabular}{|c|c|c|c|c|}
\hline & \multicolumn{2}{|c|}{$\begin{array}{c}\text { Labor migrants at } \\
\text { HSE1 }\end{array}$} & \multicolumn{2}{|c|}{$\begin{array}{c}\text { Not labor migrants } \\
\text { at HSE1 }\end{array}$} \\
\hline & Women & Men & Women & Men \\
\hline $\begin{array}{l}\text { Household lost female pensioner } \\
\text { HSE2 - HSE1 }\end{array}$ & $\begin{array}{l}-0.048 \\
(0.054)\end{array}$ & $\begin{array}{l}-0.038 \\
(0.042)\end{array}$ & $\begin{array}{l}-0.032 \\
(0.016)\end{array}$ & $\begin{array}{l}-0.046 \\
(0.022)\end{array}$ \\
\hline $\begin{array}{l}\text { Household lost male pensioner } \\
\text { HSE2 - HSE1 }\end{array}$ & $\begin{array}{l}-0.045 \\
(0.061)\end{array}$ & $\begin{array}{l}-0.002 \\
(0.043)\end{array}$ & $\begin{array}{l}-0.010 \\
(0.020)\end{array}$ & $\begin{array}{c}0.008 \\
(0.026)\end{array}$ \\
\hline $\begin{array}{l}\text { Household gained female pensioner } \\
\text { HSE2 - HSE1 }\end{array}$ & $\begin{array}{l}-0.014 \\
(0.042)\end{array}$ & $\begin{array}{c}0.029 \\
(0.033)\end{array}$ & $\begin{array}{c}0.086 \\
(0.014)\end{array}$ & $\begin{array}{c}0.039 \\
(0.018)\end{array}$ \\
\hline $\begin{array}{l}\text { Household gained male pensioner } \\
\text { HSE2 - HSE1 }\end{array}$ & $\begin{array}{c}0.059 \\
(0.066)\end{array}$ & $\begin{array}{c}0.051 \\
(0.045)\end{array}$ & $\begin{array}{c}0.032 \\
(0.020)\end{array}$ & $\begin{array}{c}0.093 \\
(0.028)\end{array}$ \\
\hline Number of observations & 2035 & 3250 & 11148 & 8489 \\
\hline
\end{tabular}

Notes. Table 8 reports the coefficients and standard errors from OLS regressions of change in the labor migration status. Also included in each regression are variables for the change in the number of resident members, and the number of days that elapsed between HSE1 and HSE2. The sample is restricted to household members greater than age 17 at HSE1 and less than 51 at HSE2. 